\title{
Dealing with the past in Latin America, South Africa and Germany
}

Tatjana Louis / Mokgadi Molope / Stefan Peters

There seems to be no issue that is timelier than the past. We can hardly imagine a day without news pertaining to the past. Dealing with a mostly conflictual, or traumatic, past has become a political issue that is negotiated not only nationally but also across the borders of countries and continents. Just as globally entangled as history is the politics of memory. A recent example in May 2021, French President Emanuel Macron recognized a shared responsibility of France for the genocide in Rwanda. The German Parliament recognized the Genocide against the Nama and Herero during their colonial rule over today's Namibia. In Latin America, a lot of the polemic on the 2021 Peruvian Presidential elections was related to the past dictatorship of Alberto Fujimori, and the crimes of Maoist Shining Path Guerrilla. In Great Britain, the US, and recently in Colombia activists tear down monuments to slaveholders and colonial masters. And in South Africa it is impossible to understand skepticism against vaccination without knowing about the medicinal atrocities committed by the Apartheid regime. In short, if we want to understand current political and social dynamics, we need to know not only about the past, but also analyze the way current societies are dealing with the past.

During the last decades, the question of how societies are dealing with the past has received increasing attention by political actors, civil society and academia. If anything can dependably confirm the mainstreaming of memory studies and transitional justice in the international debate, it is the number of handbooks recently published on the topic (see e.g. Erll \& Nünning, 2010; Buckley-Zistel et al., 2014; Tota \& Hagen, 2016; Lawther et al., 2017; De Nardi et al., 2020). Yet, dealing with the past continues to be a very controversial issue. Indeed, the above-mentioned examples have all caused fierce controversies and polemic debates. It is striking that these debates take place not only about recently overcome events and periods, but the focus is increasingly on coming to terms with injustices that occurred longer ago, as for example colonialism. Even the memory of pasts for which a routine of remembering has long been established, such as the memory in Germany of the human rights crimes committed 
by the National Socialists, are repeatedly questioned and renegotiated. This is due to the fact that there is no definitive answer to the question of the "right" way to deal with the past. It is up to each generation to justify anew for itself why, how, and with what end historical events should be remembered.

It is obvious that there is no patent remedy for successfully coming to terms with the past. This process is highly context dependent. Each society and each generation must seek the path that is appropriate for them and ascribe its own meaning to the past knowing that there will never be a total consensus on how to deal with the past. This is no surprise. Conflict is essential to modern politics and societies, dealing with the past is no exception.

The comparative view beyond the society's own limits is important and useful. For example, to benefit from experiences of longer-term memory processes, to find a different approach, or to reflect on one's own practices from the outside. This book is a result of are an ongoing trilateral project "Transitional Societies"; a cooperation between the University of Gießen in Germany, the Universidad de los Andes in Colombia, and the NorthWest University in South Africa and funded by the German Academic Exchange Service (DAAD) from which this publication emerges. ${ }^{1}$ With these three countries, we connect not only three continents, but also three societies that are at different moments of their respective memory processes. With the commemoration of the Holocaust, Germany is already at the extreme limit of a communicative memory (Assmann, 2016) and faces the challenge of passing on this memory in a meaningful way to the now third or fourth post-war generation. However, this is not to state that Germany has done its 'memory work'. For example, a debate about the persecution of socially disadvantaged groups during national socialism and the continued discrimination against them has hardly begun (Wiedemann, 2019; Lölke \& Staats, 2021). Moreover, the atrocities committed by German colonizers only recently got broader public attention thanks mainly to the pressure from the former colonies and civil society activists in Germany. The issue of colonialism is also linked to questions of how to deal today with cultural heritage stolen by colonial powers as shown by the discussions on the new Humboldt Forum in Berlin (Morat, 2019; Habermas, 2019; see also the contribution by Kößler and Melber to this volume). Of course, the increasing debate on colonialism can also be seen

1 For further information about the project see: https://www.transitional-societies. org. 
in other European countries. For example, in the Netherlands there is a polemic debate on the legacy of colonialism and racism (Wekker, 2016: Ariese, 2020). Moreover, we can observe a growing social sensitivity, for example, in the case of streets and squares named after colonial masters or the colonial and racist roots of cultural habits (Ward \& Rocha, 2018; Dikmans, 2020). Nevertheless, there is also a recognition of responsibility for human rights crimes, or the theft of cultural assets that occurred in colonial contexts. However, colonial violence also left enduring legacies. For the case of German colonialism, Apoh and Mehler (2021: 55) highlight that the violent land expropriation under German colonial rule continues to have socio-economic consequences in the current plantations economy in the South-West of Cameroon.

In South Africa, more than 25 years after the end of the Apartheid regime, the shadows of the past are still very present. There is no doubt that the South African society continues to suffer from the legacies of the Apartheid regime. The transition towards democracy in South Africa represented a landmark moment with an enthusiastic reaction both within and beyond the country. In the context of the political transition, the importance of dealing with the violent past was addressed right from the beginning. In the country's quest for democracy and to end more than 50 years of human rights violations and atrocities, South Africa mandated the Truth and Reconciliation Commission (TRC) through the Promotion of National Unity and Reconciliation Act 34 of 1995, to establish the cause and nature of these inhumane actions thus paving a way for granting of amnesty to those who make full confessions (Pityana, 2018). The TRC was "the fruit of a political compromise" (Mamdani, 2002: 33) and based in the recognition by both the political movements and the Apartheid regime that a peaceful transition was necessary (van Zyl, 1999). It started its work in 1996, presenting the first five volumes of its report in 1998. The TRC focused on restorative justice ${ }^{2}$ and reconciliation. Although, by far, not the first truth commission in history (see also the contribution of Figari Layús to this volume), the South African TRC was groundbreaking for international debates on transitional justice and human rights (Gready, 2011). Vori and Vori (2004: 305) even argue that the TRC was "one of the most remarkable efforts of peace making in our times." Yet, there is also harsh criticism on the TRC. Mamdani (2002) argues that the TRC individualized the victims and failed to understand the nature of the

2 For a discussion on restorative justice see e.g. Clark (2008) and de Gamboa Tapias (2020). 
apartheid regime. Moreover, he criticizes the non-criminalization of the perpetrators of human rights violations and holds that the country would have needed a combination of political reform and judicial reconciliation (Mamdani, 2002; Mamdani, 2015). Therefore, this could be the reason why victims still hold that despite the extent of its success by giving a voice to the silenced (Gready, 2011), the TRC has not facilitated justice to some of the victimized. The yet to be prosecuted 300 hundred cases referred to the National Prosecuting Authority by the Truth and Reconciliation Commission confirms concerns of lack of justice raised by the victims and their families. From a different perspective, Gready (2011: 2) criticizes the lack of conceptual clearness in the work of the TRC. Yet, there is another issue that gets increasing attention in recent times. South Africa witnessed a comparatively successful political transition although the socio-economic legacies of the apartheid continue to be conspicuous. The country notoriously leads the ranking of the most unequal countries of the world. The extreme social inequalities increasingly raise the attention of international media (Time, 13-05-2019). Arguably, the transition afforded a few individuals social upward mobility, ${ }^{3}$ but social stratification and social segregation hardly changed. This exposes a well-known gap in both practice and scholarly work on political transitions and transitional justice: socio-economic change or transformation is generally not considered, and if so, it is not to be a priority. Consequentially the social grievances by the victims of the apartheid regime continue to exist, and there it seems that the transitional process ends up in a situation where "the marginalized are remarginalized" (Gready, 2011: 8).

Despite the ongoing peace process, one could argue that Colombia has not even ended the conflict that needs to be dealt with but has begun the reconstruction of a historical memory before the present could turn into a past. This situation, which the Colombian historian Gonzalo Sánchez calls circular memories (Sánchez 2006), presents a very special challenge for the creation of a meaningful memory. For Colombia it should be noted that the approach to the recent past brings the country's entire history under review. Questions, such as the reasons for the conflict that has lasted for over 50 years, very quickly lead to the structural inequality that ultimately has its origins in colonial structures in society that have not been overcome.

3 However, a recent OECD (2018) report reveals the lack of social upward mobility in South Africa. According to the OECD (2018: 27) in South Africa it takes nine generation to achieve the mean income for those born in low-income families. From the countries analyzed by the OECD only in Colombia there is less social upward mobility. 
Yet, the memory of the past might trigger current political discussions and perhaps even political change. With an expansion of the concept of victimhood, which has gained increasing social recognition in the last 15 to 20 years, traditionally disadvantaged groups such as indigenous communities can back up their demands with historical-political arguments. The bringing down of statues depicting colonial masters, as happened several times recently in Colombia in the context of violent protests between April and June 2021, is striking evidence that historical injustices are long-lasting and that the descendants of historical victims want to renegotiate these events, which are long beyond the limits of communicative memory, and include the voices of the oppressed in the national narrative.

In South Africa the post-colonial state undertook measures for institutional change (Gatsheni, 2012). In both public and private institutions, the challenges included to increase ethnic diversity and to reduce the influence of occidental thinking. However, the state did not give priority to these promises. This led to demands for the decolonization of the public spaces, buildings, universities etc. A crucial case was the removal of the statue of Cecil John Rhodes from the campus of the University of Cape Town. In the debates, Achille Mbembe (2015) dismissed in one of his public lectures on Decolonizing knowledge and the question of the archive the view that removal of colonial statues such as that of Rhodes is tantamount to erosion of history. He rather argues that such statues must be placed in museums for narrations that aim to demythologize history and whiteness in South Africa.

\section{Dealing with the Past in Latin America, South Africa and Germany}

This publication contributes to an exchange of dialogue on experiences from a transnational and transregional perspective, focusing on a) the legal issues of coming to terms with a conflictive and traumatic past, b) the memory policies that have resulted from the legal process and its impact on society, and c) finally on education as a central tool for a sustainable dissemination of historic memory in society.

Rosario Figari Layús addresses the normative side of transition processes in her contribution on Transitional Justice in Latin America. She describes which perspectives of transitional justice have been primarily adopted in Latin America and how they have affected the process of coming to terms with the past, the prosecution of perpetrators, and the treatment of victims. In doing so, she succeeds in demonstrating not only the scope, but 
also, and foremost the limits of legal processes of coming to terms with the past.

Sethulego Matebesi also focuses on the limits of the transition process by raising the question of their sustainability. In his contribution to Transitional Justice in South Africa, he discusses the need for civic participation and political trust in institutions to bring about sustainable change in society. The South African Truth and Reconciliation Commission (TRC) has a much-celebrated model character, and it has proved to be critical in advancing the country's transformative agenda. Matebasi argues that the interface between participation and political trust is significant in promoting or preventing the capacities to implement and sustain complex institutions that are supposed to engender a sustainable memory culture. It concludes by calling for renewed attention and action to embody a sustainable memory culture in contemporary South Africa.

Afterwards, Stefan Peters opens the debate on memory with a conceptual contribution to the topic. He discusses recent publications that argue "in praise of forgetting” (Rieff, 2016), highlighting the fragility of the advances regarding the social and political recognition of the value of remembering the past. Peters argues that there are different types of forgetting and he focuses on those that should better understood as silenced pasts. Thereby he highlights the importance of power relations and social inequalities for understanding whose memories are listened to and which memories are excluded from the public sphere.

In the following chapter, Reinhard Kößler and Henning Melber deal with a particular case of 'selective commemoration'. They introduce theoretical debates on dementia, amnesia and aphasia before focusing on German colonialism and particularly the genocide against the Herero and Nama in today's Namibia. The authors discuss the German debate on the issue and highlight the hard struggles to bring the topic into public debate. Moreover, they particularly highlight the way the right-wing party Alternative für Deutschland (AfD) works to downplay the genocide. Thereby they show the ongoing struggle related to the genocide and its memory in Germany.

In the next contribution, Mokgadi Molope deals with memory in South Africa and links the discussion about the legacies of the Apartheid regime to the current Covid-19 pandemic and higher education.

José Fernando Serrano addresses the discussion through the concept of reconciliation, being one of the most elusively used, but also contested, ideas in dealing with past wrongs and present injustices. The politics and policies deployed to deliver reconciliation risk impose unilateral and restricted agreements which can cause social justice issues to stay unresolved or are displaced to other arenas. With the cases of Colombia and Australia, 
Serrano shows how the different national approaches - community-based efforts lead by the civil society in Colombia and state-lead national policies in Australia - are made concrete through different social pedagogies that, nonetheless, in both cases reproduce old injustices and shape new ones.

Afterwards Enrique Chaux, Alexander Ruiz, María Andrea Rocha, Juliana Machado, Juana Yunis, Laura Bastidas and Charlotte Greniez bring the discussion on memory to the field of education. In their article, the authors discuss the way how the past is dealt with at Colombian schools. They later present four initiatives on dealing with the past in educational surroundings in Colombia. Based on their empirical work they highlight problems, dilemmas and tensions on dealing with the past in the Colombian postconflict context.

Tatjana Louis and Jennifer Cantillo examine in their chapter the language used to refer to the concepts of war and peace through an examination of history textbooks whose socially accepted discourses and worldviews at a given moment are manifest, and where the contents and narratives are found that society would like to pass on to its future citizens. With an analysis of Colombian schoolbooks from different moments in time, they show how the words and constructions used in the different narratives justify or delegitimize actions, visibilize or blur actors and assign responsibilities and agency.

At the end of this volume, Nico Weinmann presents his work based on teaching holocaust in Germany. He argues that historical-political education should not be limited to history or social sciences, but rather should be a cross-sectional task. In order to highlight the potential of such an approach he discusses the well-known Anne Frank diary and highlights its potential for both historical and literally learning. Based on this example, Weinmann claims that more cross-sectional work should be done. However, this would also need interdisciplinary teacher training and more financial and time resources for such approaches.

The contributions offer an approach through multiple perspectives on the common subject of how to deal with the past. They address the topic from a variety of disciplinary and theoretical backgrounds, thus providing an overview that aims to bridge the gap between different regional contexts by highlighting the shared challenges and tensions.

\section{Literature}

Apoh, Wazi \& Mehler, Andreas (2021): Vom Rande aus betrachtet: Das Humboldt-

Forum und die Restitutionsdebatte. In: WeltTrends. N 179, 54-58. 
Arriese, Csilla E. (2020): Amplifying Voices: Engaging and Disengaging with Colonial Pasts in Amsterdam. In: Heritage \& Society, 13 (1-2), 117-142.

Assmann, Aleida (2016): Shadows of Trauma: Memory and the Politics of Postwar Identity. New York: Fordham University Press.

Buckley-Zistel, Susanne et al. (2014): Transitional Justice Theories. New York: Routledge.

Clark, Janine Natalya (2008): The Three Rs: Retributive Justice, Restorative Justice and Reconciliation. In: Contemporary Justice Review, 11 (4), 331-350.

De Gamboa Tapias, Camila (2020): La Justicia Restaurativa en la Justicia Transicional: una reflexión general para el caso colombiano. CAPAZ Documento de Trabajo 4-2020. Bogotá: Instituto CAPAZ.

De Nardi, Sarah (2020): The Routledge Handbook of Memory and Place. New York: Routledge.

Dikmans, Bas (2020): 'Everyday Racism', 'White Innocence', and Postcolonial Society: A Deeper Look into the Durch Cultural Archive. In: Journal of Critical Race Inquiry, Vol. 7 (1), 46-66.

Erll, Astrid \& Nünning, Ansgar (2010): A Companion to Cultural Memory Studies. Berlin: De Gruyter.

Gready, Paul (2011): The Era of Transitional Justice: The Aftermath of the Truth and Reconciliation Commission in South Africa. Oxford: Routledge

Habermas, Rebekka (2019): Restitutionsdebatten, koloniale Aphasie und die Frage, was Europa ausmacht. In: ApuZ, 40-42/2019, 17-22.

Lawther, Cheryl et al. (2017): Research Handbook on Transitional Justice. Cheltenham: Edward Elgar.

Lölke, Janna \& Staats, Martina (2021): richten - strafen - erinnen: Nationalsozialistische Justizverbrechen und ihre Nachwirkungen in der Bundesrepublik. BadenBaden: Nomos.

Mamdani, Mahmood (2015): Beyond Nuremberg: The Historical Significance of the Post-Apartheid Transition in South Africa. In: Politics and Society, Vol 43 (1) 61-88.

Mamdani, Mahmood (2002): Amnesty or Impunity? A Preliminary Critique of the Report of the Truth and Reconciliation Commission in South Africa (TRC). In: Diacritics, 32 (3-4), 32-59.

Mbembe, Achille (2015): Decolonizing Knowledge and the Question of the Archive. https://worldpece.org/content/mbembe-achille-2015-0E2\%80\%9Cd ecolonizing-knowledge-and-question-archive\%E2\%80\%9D-africa-country.

Morat, Daniel (2019): Katalysator wider Willen: Das Humboldtforum in Berlin und die deutsche Kolonialvergangenheit. In: Zeithistorische Forschungen, $\mathrm{N}^{\circ}$ $16,140-153$.

OECD (2018): A Broken Social Elevator? How to Promote Social Mobility. Paris: OECD.

Pityana, Barney (2018): The Truth and Reconciliation Commission in South Africa: Perspectives and Prospects. Journal of Global Ethics Vol 14 (12) 194-207. 
Rieff, David (2016): In Praise of Forgetting: Historical Memory and its Ironies. New Haven: Yale University Press.

Sánchez, Gonzalo (2006): Guerras, memoria e historia. Medellín: La Carreta.

Tota, Anna Lisa \& Hagen, Tever (2016): Routledge International Handbook of Memory Studies. New York: Routledge.

Van Zyl, Paul (1999): Dilemmas of Transitional Justice: The Case of South Africa's Truth and Reconciliation Commission. In: Journal of International Affairs, 52 (2), 647-667.

Vora, Jay A. \& Vora, Erika (2004): The Effectiveness of South Africa's Truth and Reconciliation Commission: Perceptions of Xhosa, Afrikaner, and English South Africans. In: Journal of Black Studies, 34 (3), 301-322.

Ward, Janelle \& Rocha, Renata (2018): ,No more blackface!‘ How Can We Get People to Change Their Minds About Zwarte Piet? In: Journal of Critical Thought and Praxis, 7 (1), 71-83.

Wekker, Gloria (2016): White Innocence: Paradoxes of Colonialism and Race. Durham: Duke University Press.

Wiedemann, Felix (2019): ,Anständige‘ Täter - ,Asoziale‘ Opfer: Der Wiesbadener Juristenprozess 1951/52 und die Aufarbeitung des Mords an Strafgefangenen im Nationalsozialismus. In: Vierteljahreshefte für Zeitgeschichte, 67 (4), 593-620. 
